and, moreover, it put it in a form which implied that it would not be impossible to implement the proposals almost at once.

Mr. Veale's first recommendation was based on the fact that universities in Britain are overcrowded and under-staffed. A great part of the extra burden which is now being borne in British universities could be shared with young postgraduates from abroadpreferably young men immediately after their appointment to lectureships at their own universities. There would be no difficulty in asking them to take a few hours teaching, by which means they could supplement their incomes without making it impossible to do research work on their own. $\mathrm{Mr}$. Veale found that the idea of combining teaching and research in this way would be welcomed by the Australian universities; and there is every reason to think that it would be to the advantage both of the teacher and of the taught.

Mr. Veale's other recommendations were closely in line with the resolutions which the Congress had passed. The discussion and the resolutions showed two things very clearly : first, a realization on the part of universities in all parts of the Commonwealth that it would be greatly to the advantage of all concerned if they could know each other better, and make more frequent exchanges of men and ideas; secondly, a determination to overcome the difficulties which are at present obstructing the way. A great deal depends on the reports which will be issued by the committees set up by the Congress at Oxford.

\section{HEALTH OF THE PEOPLE OF BRITAIN}

$\mathrm{T}$ HE report of the Ministry of Health for the year ended March 31, 1947 (Cmd. 7441, pp. 1-204. London: H.M. Stationery Office, 1948. 3s. 6d. net), records, in general, another favourable bill of health. In spite of the continuance of rationing and other controls, and of the various additional ingredients of that too-familiar conception 'austerity', the vital statistics and other features of this report suggest that austerity is not really doing the population of Britain very much harm. In the period covered by the report the birth-rate rose to $19 \cdot 1$ per thousand of the population, a figure which is the highest recorded since 1923; and the infant mortality-rate fell to 43, which is a new low record. Maternal mortality also fell to a record low level of 1.43 per thousand total births, and death-rates at ages of less than fifteen years from measles, scarlet fever, rheumatic fever and heart disease were all the lowest ever reported. The death-rate was $12 \cdot 0$, which is the lowest since the previous best $(11 \cdot 6)$ in 1938 .

One of the outstanding features of the year was the success of the diphtheria immunization policy. Deaths from this disease numbered 472 , instead of the 2,361 reported in 1938, and there was a fall of 36 per cent in the notifications of diphtheria as compared with the year 1945. The greatest proportional decline was in the age-group 5-10 years (42 per cent), and the next greatest in the age-group $10-15$ years (39 per cent). These figures speak for themselves; but the warning is issued by Sir Wilson Jameson that continual control of the antigens used for the immunization and maintenance of a high proportion of immune children are essential if this excellent result is to be maintained.

Encouraging also is the fact that in 1946 new low records were reported for deaths in Britain from respiratory and other forms of tuberculosis. In 1946 the number of deaths from this cause was 22,847 , whereas ninety years ago it was 66,000 in England and Wales among a population half its present size. The report wisely avoids complacency about this advance in the control of a disease which still causes nearly one third of all deaths at ages between fifteen and thirty-nine. More beds for tuberculous cases are urgently required to accommodate the long waiting lists, and just as urgent is the need for more staff. If, says the report, the staff had been available, half the patients awaiting treatment could have been given beds during the last two years.

Notifications of whooping cough were higher than in 1945, a fact which will not surprise the parents of young children; but deaths from this distressing disease were lower. A reliable prophylactic vaccine has yet to be found, but experimental work on this problem is being energetically continued.

A serious feature of the report is the great increase of syphilis. New male cases at treatment centres rose to 10,705 , a figure which is nearly double that of the previous year. Female cases, on the other hand, were 6,970 compared with 5,527 in 1945. An increase of 1,654 in the deaths from cancer is also recorded; but the report emphasizes that modern methods of treatment of this disease can do much to relieve the pain and suffering that it causes.

Among the many interesting facts recorded in the report is the slight decline since the middle of 1945 of about three-quarters of a pound in the average weights of adults aged twenty-five to fifty-four; but the improvements in the heights and weights of school children recorded during the later years of the War have been, on the whole, maintained. Nutritional surveys have shown that only 33 out of 7,216 persons in various parts of Britain could be classified as badly nourished.

During the first six months of 1946, smallpox was a continual menace because of the heavy return traffic from India by sea and air; but the energetic action of the health authorities confined the outbreaks that occurred within narrow limits. Readers of this part of the report will realize how much steady and unrecorded work is continually being done to safeguard the health of the people; and travellers by sea and air who read it in conjunction with the section dealing with the control of airborne and seaborne disease will understand that any regulations to which they have to submit when they enter Britain are not lightly imposed. In these days of rapid travel over great distances, it is clearly the duty of every traveller to see that he does not wittingly carry into the country which he visits diseases which may be deadly to the people living there.

It is not possible in a short review to record all the other interesting features of this comprehensive report. Apart from the facts it gives about the incidence of diseases other than those mentioned above, it includes discussions of the work of the emergency public health laboratory service, now a permanent feature of the medical organisation of the country, and of the excellent work being done on all aspects of maternal care, nutrition, the improvement of hospitals and their conflict with the building restrictions, water supplies, health publicity and other aspects 
of that proteus which we call public health. If there be anyone who doubts that the best effort and brains are being employed in this beneficent work, he should read this report and learn the truth. It will tell him, not about politics, but solely about the control and relief of suffering and the maintenance of the health of everybody. For that reason all those whose work is recorded or implied in its pages must feel gratified that their efforts have produced, in spite of the difficulties of these times, so much that is positive good and so much, also, that points to even greater achievements in the future.

G. LAPAGE

\section{BRITISH COUNCIL}

\section{ANNUAL REPORT}

T HE report of the British Council for the year ended March 31, 1948, refers to the withdrawal of its activities from Iceland, Switzerland, French North Africa, Bolivia, Ecuador and Paraguay and the closing of institutes and provincial offices in Belgium, the Netherlands, the Argentine, Colombia, Chile and Peru. To meet the reduction in funds for $1948-49$ from $£ 3,500,000$ in $1947-48$ to $£ 3,150,000$, further reductions in services such as books, drama and films are also being made. During the year, however, the educational work of the Council has steadily developed. It has continued to secure or to recommend British candidates for posts in foreign universities, and forty-two posts, mostly professorships and lectureships, are now subsidized and filled by the Council, and of these ten were filled in 1947-48. The Council has also assisted in the recruitment of suitably qualified staff from Britain for British and foreign schools in many countries overseas, and during the year launched a new scheme of bursary awards designed to bring to the United Kingdom persons who would not normally qualify to obtain scholarships but who, being actively engaged in industry or professional work, would benefit from a short stay in Great Britain and from mixing with those of like occupations.

The large volume of scientific bibliographical inquiries and requests for scientific information has made it necessary to amalgamate the science libraries and scientific information services. Assistance was given to the convening bodies of scientific conferences held in the United Kingdom, and a conspectus of current scientific research in Britain has been compiled and is maintained with the co-operation of numerous bodies and by visits of Council staff to university research departments. The publication Monthly Science News has been replaced by the larger journal British Science News, and assistance has been given in placing agricultural scholars of the Council and in arranging tours for some fifty agricultural visitors. The collection of seed samples from a large number of countries was organised at the request of various research stations, and advice and assistance given to 103 private students from ten countries and to 32 engineers and technicians from thirteen countries on visits to Great Britain. The medical library and information service has expanded considerably, most of the 284 books added being received for review in the British Medical Bulletin, while 310 copies of the monthly list of new British medical publications are eirculated to libraries and institutions abroad.
Programmes of work were arranged for more than forty overseas medical graduates holding British Council scholarships, and the Council is also arranging programmes or accommodation for most of the 'fellows' appointed by the World Health Organisation who elected or were advised to study in Britain. The Council's organisation for receiving visitors was increasingly used by Government departments, overseas Governments, universities and professional societies. Besides the 599 who came as the Council's guests, forty per cent of whom were concerned with science, medicine, agriculture and engineering, 306 who came without financial assistance from the Council had programmes arranged for them. The Council also financed a limited number of delegates to scientific conferences and cultural events, and was also invited by several universities to assist recruitment for their summer schools. The Council took the initiative in convening a committee representing British universities to discuss the possibility of organising a series of summer schools in 1948, designed particularly for American students. The scheme involves a total of 700 students, for nearly 200 of whom from overseas the Council has accepted responsibility.

Reports on activities overseas are considerably curtailed in comparison with previous reports and contain little reference to scientific activities except in Finland, Italy, Poland and Brazil. The slightness of the accounts of the scientific activities of the Council constitutes one of the chief criticisms of the report, although the figures quoted for exchange of students and the like do not suggest that science is not well represented in the Council's activities, or support the impression that might be derived from other passages of the report that the Council is becoming increasingly an instrument of political warfare.

It is perhaps natural that, in view of the searching examination to which the activities of the Council were subjected by the Select Committee on Estimates in a report published last April, some space should be given to comment on the Select Committee's report. While satisfied that the evidence indicated that the Council is regarded as outside politics and that its work is not associated with propaganda or the political feeling of the day, the Select Committee directed attention to the need for introducing an improved permanent service, and questioned the necessity for so heavy a staff at headquarters. Without going elosely into the important question of recruitment, the report indicates that the British Council itself leans towards the view of the Select Committee that Civil Service standards should be applicable in recruiting the bulk of its staff. No agreement has yet been reached, however, on the question of the grades and conditions of service which will ensure the maintenance of efficiency everywhere and adequate representation overseas, nor does the fundamental question appear to have been considered whether the service of the Council should constitute a closed service or whether its staff should comprise mainly those seconded for fairly short periods and then returning to academic life or their normal occupation. The Council hopes for some reduction in staff as a result of careful overhaul of establishments at headquarters, but fears that the financial savings will be absorbed by overdue improvements in staff conditions. Staff questions may not figure so prominently in future reports, but whether they do or not, the report might reasonably be expected to provide fuller public explanation as to how and by whom the plans for our cultural strategy are prepared. 